\title{
SOCIO DEMOGRAPHIC VARIABLES' IMPACT ON HOSPITALIZED PATIENT SATISFACTION IN ALBANIA
}

\author{
Rezarta Kalaja, Ph.D. cand, \\ Full time lecturer at Professional Studies, Durres University, \\ rezartak@yahoo.com \\ Redi Myshketa, Ph.D. cand. \\ Full time lecturer at Faculty of Business, Durres University, \\ Redi.myshketa@gmail.com
}

\begin{abstract}
: patient satisfaction is one of the several ways to evaluate quality of health service, composing an effective indicator to measure the success of hospitals. In this context determining main factors that contributes in patient satisfaction is crucial to improve quality in healthcare delivery. Respective literature suggest that socio-demographic factors serve as main drivers for patient satisfaction, therefore through this article based on the ground survey methodology it is measure the existing linkages between gender, age, level of education and incomes and patient satisfaction in albania.
\end{abstract}

Keywords: patient satisfaction, age, gender, education, incomes

\section{Literature Review}

Patient satisfaction has emerged as an increasingly important health outcome and is currently used for distinct purposes such as (i) to compare different health care programs or systems;(ii) to evaluate the quality of care, (iii) to identify which aspects of a service need to be changed to improve patient satisfaction and (iv) to assist organizations in identifying consumers (Jackson et.al, 2001). This help policy makers, health care managers and physicians to identify the reasons of patient dissatisfaction and design potential interventions to enhance their satisfaction with health care system. Patient characteristics such as age, ethnicity, sex, socioeconomic status, education, and marital status are often used globally in patient expectation surveys as a proxy measure for patient expectation. According to Hall et.al (190), Sitzia et.al (1997), Worthington (2005),Naser et.al, (2012), Afzal et.al (2014) older and poor people have lower expectations thus likely to be more satisfied with health care than do younger and rich people, while higher level of education is associated with lower level of patient satisfaction as educated patients are more likely to have good understanding of disease and they expect a better communication from health care providers. Other similar surveys were carried out even by Schoenfelder et al. (2011) for measuring patient satisfaction in German hospital and the main findings related to socio demographic factors especially regarding to gender and age, were consistent with most prior research that found similar satisfaction scores among men and women and older patients being more satisfied with received services than younger individuals. One possible reason regarding the higher satisfaction rating of older study participants could be that older patients may be treated differently, e.g. more gently than younger ones.. However, the relation between global satisfaction and age faded when examining with multivariate techniques. The same is also tested for other countries and confirmed by Ibraheem et.al (2013) where a statistically significant association was found between sex, religion, age, occupation, education and satisfaction. As per their study higher satisfaction rating reported among the elderly may be due to the fact that they have lower expectations and are likely to be satisfied with minimal whatever they are given. The same applies to the level of education, and incomes. While, Havil and et.al (2005), and later on Madigan (2014) would certainly accept the role of demographic factors on patient satisfaction level but as per them the finding 
are inconclusive, depending by the individuals and ethnicity asked.

\section{Methodology}

For the purposes of this study that measure hospitalized patient satisfaction as per socio demographic variables, a ground survey was conducted in main hospital institutions in biggest cities in Albania. The number of patients is considerable to get accurate and representative results as per the methodology used. Thus the study population consist of 800 random hospitalized patients of different ages, gender and level of incomes have been asked both in public and private hospitals. Cities selected are Tirana (the capital) with 350 patients, followed by Durres with 150 patients and cities like Vlora, Fieri, Shkodra, Lezha, Kavaja, and Kruja with 50 patients each. As survey methodology collect data based on the questionnaire, when drafting it attention was paid in two main elements such as reliability and validity. To assess data validity "field expert" techniques is used which had cooperate in revising the questionnaire that is founded on SERVQUAL method. Questions are formulate in a way to easily select predefined answers inquired in the questionnaire as per Liker scale and also by using affirmative "yes" or " no" questions. Data gathered for a two month period from July - September 2015, are elaborated with a confidence level of $95 \%$ and $3 \%$ margin error.

\section{Analysis}

\subsection{Age of Patients:}

With regard to the age of the patients, $32 \%$ of them were aged more than 60 years, which is somehow excepted as this age- group need higher precaution and hospital care, followed by the age group of $46-60$ years in $29.4 \%$ of cases. $25.9 \%$ of patients asked were between 31-45 years old while $12.7 \%$ were between 18-30 years old.
Research Question 1: Are there any difference between age groups of patients in terms of hospital service satisfaction received from the public and private health institutions? In case yes, which is the age group that mostly appreciate satisfaction?

Analysis of this research questions are obtained through Levene's Test, ANOVA and Tukey test. Levene's test results noted that age group and their satisfactions are not homogeneous between them since significance value $=0.01<0: 05$, while according to ANOVA analysis differences between these two variables is statistically relevant because significance value $=0.000$ $<0: 05$ when Fisher value $F(3,796)=$ 13,858 stating the importance of differences between age groups in assessing health satisfaction services. Moreover, based on these results it is important to assess where statistical observations have more variances. This can be measure by using Post -hoc analysis as per Tukey Test. The results shown in the table below indicate that the most important differences are evaluated between age group of [18-30] and [31-45 years, as per the significance value $=0.000$ $<0: 01$ which shows that between these two patients' group there are statistically significant differences appreciating health care services. The age group varying from [18-30] has higher average value $M=4.28$ vs the age group varying from [31-45] with an average value $M=3.94$. This difference can be interpreted as this group age rarely goes to hospitals and might have encountered not quality services. Even the patients belonging to the group age of [3145] have differences with those belonging to the group that is elder than 60 years old since the latter significance value. $=0.000$ $<0: 05$, and $\mathrm{M}=4.35$. Besides these figures, these elderly group age have statistically significant differences of service satisfaction assessment level comparing to the age belonging to [46-60] because its significance value $=0.02<0.05$. To conclude all these statistical facts are in compliance with the reality as elder people are frequent users of health institutions, 
where beyond 45 years old they devaluate health satisfaction services in both private

Table 3.1.1: Levene's Test Results

\begin{tabular}{|l|c|c|c|}
\hline Levene Statistic & df1 & df2 & Sig. \\
\hline 5.611 & 3 & 796 & .001 \\
\hline
\end{tabular}

and public institutions.

Table 3.1.2: ANOVA Analysis Results

\begin{tabular}{|l|l|l|l|l|l|}
\hline & Sum of Squares & df & Mean Square & F & Sig. \\
\hline Between Groups & 20.673 & 3 & 6.891 & 13.858 & .000 \\
\hline Within Groups & 395.813 & 796 & .497 & & \\
\hline Total & 416.486 & 799 & & & \\
\hline
\end{tabular}

Table 3.1.3: Tukey Test Results

\begin{tabular}{|c|c|c|c|c|c|c|}
\hline \multirow[b]{2}{*}{ (I) Age } & \multirow[b]{2}{*}{ (J) Age } & \multirow[b]{2}{*}{ Mean Difference (I-J) } & \multirow[b]{2}{*}{ Std. Error } & \multirow[b]{2}{*}{ Sig. } & \multicolumn{2}{|c|}{ 95\% Confidence Interval } \\
\hline & & & & & Lower Bound & Upper Bound \\
\hline \multirow{3}{*}{$18-30$ years } & $31-45$ year & $.336^{*}$ & .085 & .001 & .12 & .56 \\
\hline & 46-60 year & .143 & .084 & .318 & -.07 & .36 \\
\hline & Over 60 years & -.073 & .083 & .812 & -.29 & .14 \\
\hline \multirow{3}{*}{$31-45$ years } & $18-30$ years & $-.336^{*}$ & .085 & .001 & -.56 & -.12 \\
\hline & $46-60$ years & $-.193^{*}$ & .067 & .022 & -.37 & -.02 \\
\hline & Mbi 60 years & $-.410^{*}$ & .066 & .000 & -.58 & -.24 \\
\hline \multirow{3}{*}{$46-60$ years } & $18-30$ years & -.143 & .084 & .318 & -.36 & .07 \\
\hline & $31-45$ years & $.193^{*}$ & .067 & .022 & .02 & .37 \\
\hline & Over 60 years & $-.216^{*}$ & .064 & .004 & -.38 & -.05 \\
\hline \multirow{3}{*}{ Over 60 years } & $18-30$ years & .073 & .083 & .812 & -.14 & .29 \\
\hline & $31-45$ years & $.410^{*}$ & .066 & .000 & .24 & .58 \\
\hline & $46-60$ years & $.216^{*}$ & .064 & .004 & .05 & .38 \\
\hline
\end{tabular}

\begin{tabular}{|l|c|c|c|c|}
\hline \multirow{2}{*}{\multicolumn{1}{c|}{ Age }} & \multirow{2}{*}{$\mathrm{N}$} & \multicolumn{3}{c|}{ Subset for alpha $=0.05$} \\
\cline { 3 - 5 } & & 1 & 2 & 3 \\
\hline 31-45 years & 207 & 3.94 & & \\
\hline 46-60 years & 235 & 4.14 & 4.14 & \\
\hline 18-30 years & 102 & & 4.28 & 4.28 \\
\hline Over 60 years & 256 & & & 4.35 \\
\hline Significance & & .051 & .228 & .766 \\
\hline
\end{tabular}

Data Source: Authors, 2015

\subsection{Gender of Patients:}

As for the gender of the patients asked $53.1 \%$ were women and $46.9 \%$ were men. This trend is in full compliance with the demographic trend of the total population in Albania as per the latest Census of 2011 conducted by INSTAT.

Research Question 2: Are there any difference between gender of patients in terms of hospital service satisfaction received from the public and private health institutions?

To evaluate any linkages between gender and health satisfaction services it is used Chi Square Test of Independence $\left(\chi^{2}\right)$, which is mainly used to assess if two qualitative variables are independent or not. When results generated from the test are low it 
shows that null hypothesis (independent variables) is not accepted meaning that the variables are dependent on each other. The procedure involves the comparison of the frequency observed (or current values) and expected frequencies if the qualitative variables would have not been correlated among them. In our analysis for a

Table 3.2.1: Chi - Square Test Results

Table 3.2.1: Chi - Square Test Results
\begin{tabular}{|l|c|c|c|}
\hline \multicolumn{4}{|c|}{ Chi-Square Tests } \\
\hline & Value & df & Asymp. Sig. (2-sided) \\
\hline Pearson Chi-Square & $.305^{\text {a }}$ & 2 & .858 \\
\hline Likelihood Ratio & .305 & 2 & .859 \\
\hline Linear-by-Linear Association & .300 & 1 & .584 \\
\hline N of Valid Cases & 800 & & \\
\hline
\end{tabular}

Data Source: Authors, 2015

\subsection{Education variable:}

Another important variable regarding the demographic aspect of the sample is the level of education of patients asked. $42.1 \%$ of all individuals asked had secondary education, out of which 85.5 are hospitalized at public institutions; followed by the primary education in $30.4 \%$ of cases, where $98.4 \%$ out of them are hospitalized at public institutions. Patients with bachelor degree has been only in $22 \%$ of cases, where $63.1 \%$ out of them are hospitalized at public institutions. Only $5.5 \%$ of patients asked had also postgraduate education level which in $72.7 \%$ of cases had chosen to be treated in private institutions.

Research Question 3: Are there any difference between patients' level of education in terms of hospital service satisfaction received from the public and private health institutions? In case yes, which is the group that mostly appreciate service satisfaction?

Even in this case results are generated from Levene's test, ANOVA analysis and confidence interval of $95 \%$ Pearson coefficient Chi Square expressed through Value df. Asymp. Sig. (2-sided) is $0.858>$ 0.05 , meaning that the null hypothesis can't be rejected. Therefore there are no differences between gender and service satisfaction.
Tukey's Test. Value of significance as per Levene's Test indicates that patients grouped as per their level of education has not an homogenies distribution as the value is $0.00<0.05$. While ANOVA analysis shows a significance value $=0.018<0.08$ for value of Fisher $\mathrm{F}(3 ; 796)=3.362$ meaning that there are statistical differences between tested variables. The results in table below clearly indicate that the highest statistical differences are between the patients that had primary and secondary education, because the value is $0.009<0.05$, and the average level of satisfaction is $\mathrm{M}$ primary education $=4.29$ while $\mathrm{M}_{\text {secondary education }}=$ 4.10 , consequently the less the level of education the higher the assessments of individuals on health service satisfaction. For the people that have education beyond these two categories no important statistical differences were observed, meaning that the more people are educated the higher are their expectations for health service qualities. 
Table 3.3.1: Levene's Test Results

\begin{tabular}{|l|l|l|l|}
\hline Levene Statistic & df1 & df2 & Sig. \\
\hline 9.985 & 3 & 796 & .000 \\
\hline
\end{tabular}

Table 3.3.2: ANOVA Analysis Results

\begin{tabular}{|l|l|l|l|l|l|}
\hline & Sum of Squares & df & Mean Square & F & Sig. \\
\hline Between Groups & 5.211 & 3 & 1.737 & 3.362 & .018 \\
\hline Within Groups & 411.275 & 796 & .517 & & \\
\hline Total & 416.486 & 799 & & & \\
\hline
\end{tabular}

Table 3.3.3: Tukey Test Results

\begin{tabular}{|c|c|c|c|c|c|c|}
\hline \multirow[b]{2}{*}{$\begin{array}{l}\text { (I) Level of } \\
\text { Education }\end{array}$} & \multirow[b]{2}{*}{$\begin{array}{l}\text { (J) Level of } \\
\text { Education }\end{array}$} & \multirow[b]{2}{*}{$\begin{array}{c}\text { Mean Difference } \\
\text { (I-J) }\end{array}$} & \multirow[b]{2}{*}{$\begin{array}{l}\text { Std. } \\
\text { Error }\end{array}$} & \multirow[b]{2}{*}{ Sig. } & \multicolumn{2}{|c|}{ 95\% Confidence Interval } \\
\hline & & & & & $\begin{array}{l}\text { Lower } \\
\text { Bound }\end{array}$ & $\begin{array}{l}\text { Upper } \\
\text { Bound }\end{array}$ \\
\hline \multirow{3}{*}{ Primary Education } & $\begin{array}{l}\text { Secondary } \\
\text { Education }\end{array}$ & $.191^{*}$ & .060 & .009 & .03 & .35 \\
\hline & Bachelor degree & .133 & .071 & .243 & -.05 & .32 \\
\hline & Postgraduate & .135 & .118 & .660 & -.17 & .44 \\
\hline \multirow{3}{*}{$\begin{array}{l}\text { Secondary } \\
\text { Education }\end{array}$} & Primary Education & $-.191^{*}$ & .060 & .009 & -.35 & -.03 \\
\hline & Bachelor degree & -.058 & .067 & .824 & -.23 & .11 \\
\hline & Postgraduate & -.055 & .115 & .963 & -.35 & .24 \\
\hline \multirow{3}{*}{ Bachelor degree } & Primary Education & -.133 & .071 & .243 & -.32 & .05 \\
\hline & $\begin{array}{l}\text { Secondary } \\
\text { Education }\end{array}$ & .058 & .067 & .824 & -.11 & .23 \\
\hline & Postgraduate & .002 & .121 & 1.000 & -.31 & .31 \\
\hline \multirow{3}{*}{ Postgraduate } & Primary Education & -.135 & .118 & .660 & -.44 & .17 \\
\hline & $\begin{array}{l}\text { Secondary } \\
\text { Education }\end{array}$ & .055 & .115 & .963 & -.24 & .35 \\
\hline & Bachelor degree & -.002 & .121 & 1.000 & -.31 & .31 \\
\hline
\end{tabular}

\begin{tabular}{|l|l|l|}
\hline & \multirow{2}{*}{ N } & Subset for alpha $=0.05$ \\
\cline { 3 - 3 } Level of Education & & 1 \\
\hline Secondary Education & 337 & 4.10 \\
\hline Postgraduate & 44 & 4.15 \\
\hline Bachelor degree & 176 & 4.16 \\
\hline Primary Education & 243 & 4.29 \\
\hline Significance & & .192 \\
\hline
\end{tabular}

Data Source: Authors, 2015

\subsection{Level of Incomes}

Round $59.5 \%$ of patients have declared to have average monthly incomes less than $30.000 \mathrm{ALL}^{4}$, and only $7.4 \%$ of them has been treated to private hospitals. Patients with incomes ranging from [30.000 -50.000]

${ }^{4}$ The minimum wage declared in the Republic of Albania as per the legal acts in force is 22.000 Albanian lek (ALL), Authors (2015) were $20.6 \%$ and $83 \%$ of them has been treated to public institutions, followed by 10 $\%$ of patients which has declared to have monthly incomes higher than 70.000 ALL, out of which $66.3 \%$ frequent private hospitals. Only $9.9 \%$ of asked patients have declared to have monthly incomes ranging [50.000 - 70.000], out of which $43 \%$ frequent private hospitals. 
Research Question 4: Are there any difference between patients' level of incomes in terms of hospital service satisfaction received from the public and private health institutions? In case yes, which is the group that mostly appreciate service satisfaction?

Even in this case results are generated from Levene's test, ANOVA analysis and Tukey's Test. Value of significance as per Levene Test indicates that patients grouped as per their level of incomes has not an homogenies distribution as the value is $0.003<0.05$. While ANOVA analysis shows a significance value $=0.003<0.05$ for value of Fisher F $(3 ; 796)=4.798$ meaning that there are statistical differences between tested variables. The results in table below

Table 3.4.1: Levene's Test Results clearly indicate that the highest statistical differences are between the patients that low level of incomes ranging [0-30.000] and also [30.000-50.000], because the value of significance is $0.003<0.05$, and the average level of satisfaction is $\mathrm{M}_{[0-30.000]}=4.23$ while $\mathrm{M}_{[30.000-50.000]}=4.00$, consequently the less the level of incomes the higher the assessments of individuals on health service satisfaction. For the people that have incomes beyond these two categories no important statistical differences were observed, meaning that the poorer the people are the lower are their expectations for health service qualities, which is linked with their constrain in affording expensive services.

\begin{tabular}{|l|l|l|l|}
\hline Levene Statistic & df1 & df2 & Sig. \\
\hline 4.626 & 3 & 796 & .003 \\
\hline
\end{tabular}

Table 3.4.2: ANOVA Analysis Results

\begin{tabular}{|l|l|l|l|l|l|}
\hline & Sum of Squares & df & Mean Square & F & Sig. \\
\hline Between Groups & 7.398 & 3 & 2.466 & 4.798 & .003 \\
\hline Within Groups & 409.088 & 796 & .514 & & \\
\hline Total & 416.486 & 799 & & & \\
\hline
\end{tabular}

Table 3.4.3: Tukey Test Results

\begin{tabular}{|c|c|c|c|c|c|c|}
\hline \multirow[b]{2}{*}{$\begin{array}{l}\text { (I) Monthly level of } \\
\text { incomes }\end{array}$} & \multirow[b]{2}{*}{$\begin{array}{l}\text { (J) Monthly level of } \\
\text { incomes }\end{array}$} & \multirow[b]{2}{*}{$\begin{array}{c}\text { Mean Difference } \\
\text { (I-J) }\end{array}$} & \multirow[b]{2}{*}{$\begin{array}{l}\text { Std. } \\
\text { Error }\end{array}$} & \multirow[b]{2}{*}{ Sig. } & \multicolumn{2}{|c|}{ 95\% Confidence Interval } \\
\hline & & & & & $\begin{array}{l}\text { Lower } \\
\text { Bound }\end{array}$ & $\begin{array}{l}\text { Upper } \\
\text { Bound }\end{array}$ \\
\hline \multirow{3}{*}{ 0-30.000 ALL } & $30000-50000$ ALL & $.228^{*}$ & .065 & .003 & .06 & .39 \\
\hline & $50000-70000$ ALL & .140 & .087 & .372 & -.08 & .36 \\
\hline & Over 70000 ALL & -.021 & .087 & .995 & -.24 & .20 \\
\hline \multirow{3}{*}{30000 - 50000 ALL } & 0-30000 ALL & $-.228^{*}$ & .065 & .003 & -.39 & -.06 \\
\hline & $50000-70000 \mathrm{ALL}$ & -.088 & .098 & .809 & -.34 & .17 \\
\hline & Over 70000ALL & -.249 & .098 & .054 & -.50 & .00 \\
\hline \multirow{3}{*}{$50000-70000 \mathrm{ALL}$} & 0-30000ALL & -.140 & .087 & .372 & -.36 & .08 \\
\hline & $30000-50000$ ALL & .088 & .098 & .809 & -.17 & .34 \\
\hline & Over 70000 ALL & -.161 & .114 & .488 & -.45 & .13 \\
\hline \multirow{3}{*}{ Over 70.000 ALL } & 0-30.000 ALL & .021 & .087 & .995 & -.20 & .24 \\
\hline & $30000-50000$ ALL & .249 & .098 & .054 & .00 & .50 \\
\hline & $\begin{array}{l}50000-70000 \\
\text { ALL }\end{array}$ & .161 & .114 & .488 & -.13 & .45 \\
\hline
\end{tabular}




\begin{tabular}{|c|c|c|c|}
\hline \multirow{2}{*}{ Monthly level of incomes } & \multirow{2}{*}{$\mathrm{N}$} & \multicolumn{2}{|c|}{ Subset for alpha $=0.05$} \\
\hline & & 1 & 2 \\
\hline $50000-70000$ ALL & 165 & 4.00 & \\
\hline $30000-50000$ ALL & 79 & 4.09 & 4.09 \\
\hline Over 70.000 ALL & 476 & 4.23 & 4.23 \\
\hline 0-30000 ALL & 80 & & 4.25 \\
\hline Signifcance & & .067 & .302 \\
\hline
\end{tabular}

Data Source: Authors, 2015

\section{Concluding Remarks}

Through this article are tested the effects of demographic factors in patient sattisfaction in Albania. The results from the survey are in full compliance with the exisiting literature with such factors such as age, level of education and incomes, meaning that older, less educated and poorer individuals have shown higher satisfaction toward the health services provided. While the gender factor for Albania does not give any direct impact on service satisfaction, even though in other studies of different countries this factor seems to have a certain indication. Other important findings that serve as special messages especially for the management of private and public hospitals and policymakers is that the more educated and richer the people are, the more they would take in consideration private hospitals. Therefore all relevant stakeholders need to swiftly react in accordance with the need of population targeting the prerequisites of their patients and treating everyone as it should be.

\section{Bibliography}

1. Afzal M, Rizvi F, Azad AH, Rajput AM, Khan A, Tariq N., (2014), "Effect of demographic characteristics on patient's satisfaction with health care facility. J Postgrad Med Inst 2014; 28(2):154-60.

2. Hall, J. A., \& Dornan, M. C. (1990). "Patient sociodemographic characteristics as predictors of satisfaction with medical care: A metaanalysis". Social Science \& Medicine (1982), 30(7), 811-818.
3. Haviland, M. G., Morales, L. S., Dial, T. H., \& Pincus, H. A. (2005). Race/ethnicity, socioeconomic status, and satisfaction with health care. American Journal of Medical Quality: The Official Journal of the American College of Medical Quality, 20(4), 195-203. doi:10.1177/1062860605275754

4. Ibraheem WA, Ibraheem AB, Bekibele CO.(2013), "Socio-demographic predictors of patients' satisfaction" African Journal of Medical and Health Sciences / Jul-Dec 2013 / Vol 12 | Issue 2

5. Jeffrey L. Jackson J.L; Chamberlin J and Kroenke K, (2001), "Predictors of patient satisfaction", University of Nebraska - Lincoln, Uniformed Services University of the Health Sciences US Department of Defense

6. Madigan C. K, (2014), “ Drivers of patient satisfaction and effects of demographics on the HCAHPS survey", University of North Carolina at Chapel Hill

7. Naseer, M., Zahidie, A., Shaikh, B. T. (2012). Determinants of patient's satisfaction with health care system in Pakistan: a critical review. Pakistan Journal of Public Health, 2(2), 52-61.

8. Schoenfelder T, Klewer J and Kugler J",(2011, May) "Determinants of patient satisfaction: a study among 39 hospitals in an in-patientsetting in Germany", International Journal for Quality in Health Care 2011; Volume 23, Number 5: pp. 503-509 10.1093

9. Sitzia, J., \& Wood, N. (1997),'Patient satisfaction: A review of issues and concepts. Social Science \& Medicine1982:, 45(12), 18291843.

10. Williams, B. (1994). Patient satisfaction: A valid concept? Social Science \& Medicine, 38(4), 509-516.

11. WorthingtonC, (2005), "Patient satisfaction with health care: recent the oritical developments and implicaitons for evaluation practice", The Canadian Journal of Program Evaluation Vol. 20 No. 3 Pages 41-63 ISSN 0834-1516 